\title{
ANALYSIS OF MATHEMATICAL COMMUNICATION ABILITY AND SELF REGULATED LEARNING MATHEMATICS STUDENT'S OF IX GRADE SMP NEGERI 2 CILAMAYA KULON
}

\author{
Fika Muji Fadhillah ${ }^{1}$, Erna Hernawati ${ }^{2}$ \\ ${ }^{1,2}$ Mathematics Education Program Post Graduate IKIP Siliwangi, Cimahi \\ ${ }^{1}$ fadhillah_fika@yahoo.com, ${ }^{2}$ ernamath@yahoo.co.id
}

Received: Jun 21 ${ }^{\text {th }}$ 2019; Accepted: Jul $17^{\text {th }}, 2019$

\begin{abstract}
This study aims to determine mathematical communication ability and mathematical self-regulated learning of IX grade students of SMP Negeri 2 Cilamaya Kulon Karawang on circle material and circle tangents. This research is quantitative research, where the object of research is IX grade students as many as 35 students. This research was conducted on November 20, 2018. This research technique is in a set of a test as many as 6 items test questions of mathematical communication ability and questionnaires with 40 items of mathematical self regulated learning. The results of this study were mathematical communication ability of students classified as moderate with a reliability coefficient of .9793, having a mean difficulty index of .539 (medium category), and a mean differentiation of .485 (good category). The students when he a matter of mathematical communication problems to the matter circle and circle mention poor students analyze the core issues, students do not understand the form of questions non-rutin (mathematical communication), students are confused in determining completion strategies, students cannot visualization, students do not know the terms in mathematics, as well as procedural errors in progress. While for self regulated mathematics students have a good category.
\end{abstract}

Keywords: Mathematical Communication Ability, Self Regulated Learning Mathematics

\begin{abstract}
Abstrak
Penelitian ini bertujuan untuk mengetahui kemampuan komunikasi matematis dan kemandirian belajar matematika siswa kelas IX SMP Negeri 2 Cilamaya Kulon Karawang pada materi lingkaran dan lingkaran singgung. Penelitian ini adalah penelitian kuantitatif, dimana objek penelitiannya adalah siswa kelas IX sebanyak 35 siswa. Penelitian ini dilakukan pada tanggal 20 November 2018. Teknik penelitian ini berupa tes sebanyak 6 butir soal tes kemampuan komunikasi matematis dan angket dengan 40 butir pernyataan self regulated learning matematika. Hasil penelitian ini adalah kemampuan komunikasi matematis siswa yang tergolong sedang dengan koefisien reliabilitas 0,9793 , memiliki indeks kesulitan rata-rata 0,539 (kategori sedang), dan diferensiasi rata-rata 0,485 (kategori baik). Kendala siswa ketika mengerjakan soal komunikasi matematis pada materi lingkaran dan lingkaran singgung adalah siswa yang kurang mampu menganalisis inti masalah, siswa tidak memahami bentuk pertanyaan non-rutin (komunikasi matematika), siswa bingung dalam menentukan penyelesaian strategi, siswa tidak bisa visualisasi, siswa tidak tahu istilah dalam matematika, serta kesalahan prosedural yang sedang berjalan. Sedangkan untuk matematika yang diatur sendiri siswa memiliki kategori baik.
\end{abstract}

Kata kunci: Kemampuan Komunikasi Matematika, Matematika Belajar Mandiri

How to Cite: Fadhillah, Fika Muji \& Hernawati, Erna. (2019). Analysis of Mathematical Communication Ability and Self Regulated Learning Mathematics Student's of Class IX 


\section{INTRODUCTION}

Mathematical communication ability become one of the requirements that play an important role because it helps in the process of composing the mind, connecting ideas with one another so that they can fill in the things that are lacking in the entire network of ideas of students. Mathematical communication ability are very important to be considered and owned by students (Asnawati, 2016; Bernard, 2015; Chotimah, 2015; Elida, 2012; Fadhillah \& Sumarna, 2017; Gardenia, 2016; Haji \& Abdullah, 2016; Hendriana \& Kadarisma, 2019; Nuriadin, 2015; Rahmi, Nadia, Hasibah, \& Hidayat, 2017; Rosita, 2008; Umar, 2012; Yuliani, 2015). This is because through mathematical communication students can organize and consolidate mathematical thinking both verbally and in writing, besides that the renegotiation of responses between students will occur in the learning process (Chotimah, 2015). Mathematical communication ability are the ability to communicate ideas that are created through mastery that students have through activities: (1) connecting real objects, images, and diagrams into mathematical ideas; (2) explain ideas, situations and mathematical relations verbally or in writing with real objects, images, graphics and algebra; (3) expressing daily events in language or mathematical symbols (Alamiah \& Afriansyah, 2017; Asnawati, 2016; Elida, 2012).

In addition to the cognitive abilities students must possess, affective abilities are equally important. Self regulated learning often referred to as learning independence is also an important part of learning mathematics, because one of the behavioral aspects that can make a school successful is student learning independence (Budiyanto \& Rohaeti, 2014; Darma, Firdaus, \& Haryadi, 2016; Haerudin, 2013; Kurnia, Mulyani, Rohaeti, \& Fitrianna, 2018; Purnamasari \& Herman, 2016). Students who are independent in learning means that students have attitudes and behaviors, feel something, reason and make decisions according to their own abilities. The success of students in learning mathematics is determined by the learning independence of each individual. Students who have high learning independence tend to learn better in their own supervision, are able to monitor, supervise, and manage their learning effectively, complete time in completing their tasks, and manage learning and time efficiently (Azka \& Santoso, 2015; Purnamasari \& Herman, 2016). Student learning independence is something that affects the quality of student learning achievement.

Mathematical communication ability have a very strong relationship with self regulated learning students. When students are able to connect real objects into tables / diagrams, state mathematical situations in the form of images, state daily events in mathematical symbols or compose mathematical models of events, then the students' attitude to learning independence will emerge. This opinion is in line with the opinion of Haerudin (2013) that with learning carried out well, it is not only increased mathematical communication skills, but learning independence will also increase. Finally what is the goal in learning will be achieved well.

Based on the results of the study that the mathematical communication ability of junior high school students in Karawang Regency are still low (Fadhillah \& Sumarna, 2017). This is because students in general are less able to understand something that cannot be seen in plain view and students are not used to working on mathematical communication ability. This is in line with the teaching experience of writers in class VII, VIII, IX in SMP Negeri 2 Cilamaya Kulon, the researcher explained that the communication and self-regulated learning ability of 
junior high school students is still lacking, students rarely conduct group discussion activities, students are not independent in study. In group discussion activities there are some students who have difficulty in conveying their thoughts, students rarely exchange opinions with other students, students are only able to solve similar questions with the example of the teacher, and when they get different types of questions students tend to give up immediately, want a teacher solve the problem.

To find out how much communication ability and self regulated learning mathematics are mastered by junior high school students, we can obtain this by providing the ability test instrument, then the data obtained are analyzed and interpreted well. However, it should be noted that the test instrument provided must be valid first. Good research should use good instruments too. One of the things that needs to be considered related to the preparation of a good instrument is about its validity. Therefore, instrument validation is one step in the activity that researchers must pay attention to before the instrument is used. By knowing more deeply about the validation of test instruments, it is expected that in research activities especially in the field of mathematics education, the instruments used are valid so that they can produce data that can truly be scientifically accountable.

\section{METHOD}

The method in this study uses descriptive qualitative research methods, where research aims to describe in full about students' mathematical abilities. The population in this study were all IX grade students of SMP Negeri 2 Cilamaya Kulon Karawang. With the sample selected 1 class randomly selected class IX C. The instrument in this study is a set of questions about mathematical communication ability consisting of 6 description questions and a self regulated learning attitude scale questionnaire consisting of 40 questionnaires. In order to have empirical validity the questions tested are then calculated for validity, reliability, differentiation and difficulty index. The collected data is then analyzed using Microsoft Excel software and IBM SPSS Statistics 20. Software data analysis includes empirical validity of each set of test instruments using the Pearson correlation formula, reliability using the Cronbach's Alpha formula, distinguishing power, and the index of difficulty of each item. Then the data analysis results are interpreted based on the modified Guilford criteria.

Tabel 1. Junior High School Mathematics Communication Ability Test Instrument

\begin{tabular}{llll}
\hline No & $\begin{array}{l}\text { Indicators of Mathematical } \\
\text { Communication Ability }\end{array}$ & Question \\
\hline 1 & $\begin{array}{l}\text { Stating real objects or images } \\
\text { into word problems and solve } \\
\text { them }\end{array}$ & $0-6$ \\
& & $\begin{array}{l}\text { Prepare a story about the relevant from the } \\
\text { image above and solve the problem! }\end{array}$ \\
\hline 2 & Stating mathematical situation & $\begin{array}{l}\text { Pak Ram purchased three the pipe to } 0-6 \\
\text { replace a leaky water lines at his home, } \\
\text { in the form of images and finish }\end{array}$ \\
& with the pipe joining two small and one &
\end{tabular}




\begin{tabular}{|c|c|c|c|}
\hline & & $\begin{array}{l}\text { large PVC pipe. The ratio of the smaller the } \\
\text { pipe with the pipe large area is } 1: 4 \text { and the } \\
\text { vast number of small PVC pipe is } 77 \mathrm{~cm}^{2} \text {. } \\
\text { Draw a picture the pipe which has been } \\
\text { arranged so that the rope used to tie a } \\
\text { minimum, then compute the length of the } \\
\text { rope used! }\end{array}$ & \\
\hline 3 & $\begin{array}{l}\text { Stating the events a day - day of } \\
\text { the mathematical symbol or } \\
\text { construct a mathematical model } \\
\text { of an event and finish }\end{array}$ & $\begin{array}{l}\text { Pak Andi will make a circular park with a } \\
\text { diameter of } 28 \mathrm{~m} \text {. In the middle - the } \\
\text { middle of the park will be made an } 14 \mathrm{~m} \\
\text { diameter circular shape. Land around the } \\
\text { pool will be planted with grass to the cost } \\
\text { Rp. } 10,500.00 / \mathrm{m}^{2} \text { and mounting labor costs } \\
\text { amounting to Rp } 250,000.00 \text { grass. } \\
\text { a. Make a mathematical model of the } \\
\text { information above! } \\
\text { b. Determine all the costs incurred by } \mathrm{Mr} \\
\text { Andi to plant the grass! } \\
\text { c. If the surrounding park and the pool will } \\
\text { be planted with flowers with flowers } 2 \\
\text { meter spacing then how many flowers } \\
\text { planted around the park and the pool? }\end{array}$ & $0-6$ \\
\hline 4 & $\begin{array}{l}\text { Stating the situation or } \\
\text { mathematical ideas in the form } \\
\text { of images and finish }\end{array}$ & $\begin{array}{l}\text { A rice mill has a wheel spokes each - each } \\
34 \mathrm{~cm} \text { and } 19 \mathrm{~cm} \text {. Singgug line grinding } \\
\text { machine rice } 1.12 \mathrm{~m} \text {. Draw the situation } \\
\text { above all in the form of images! Then } \\
\text { calculate the distance between the two } \\
\text { wheels grinding the rice! }\end{array}$ & $0-6$ \\
\hline 5 & $\begin{array}{l}\text { Portray or represent any actual } \\
\text { or image into the form of a } \\
\text { mathematical word problems. }\end{array}$ & $\begin{array}{l}\text { Add information or the size of the image } \\
\text { above, then craft a relevant word problems } \\
\text { and solve these problems! }\end{array}$ & $0-6$ \\
\hline 6 & $\begin{array}{l}\text { Develop a mathematical model } \\
\text { of an daily activity and solved }\end{array}$ & $\begin{array}{l}\text { A factory making biscuits shaped solid } \\
\text { circle with a diameter of } 6 \mathrm{~cm} \text {. As a } \\
\text { variation, the plant also wish to make } \\
\text { cookies with the same thickness but pie- } \\
\text { shaped circle with a central angle of } 900 \text {. } \\
\text { a. Create a mathematical model to } \\
\text { determine the circumference of biscuits } \\
\text { produced by the plant is then complete! } \\
\text { b. Specify finger - the finger-shaped biscuit } \\
\text { pie so that the same production materials } \\
\text { with biscuits circular }\end{array}$ & $0-6$ \\
\hline
\end{tabular}


22 Fadhillah \& Hermawati, Analysis of Mathematical Communication Ability and Self Regulated Learning Mathematics Student's of Class IX SMP Negeri 2 Cilamaya Kulon

\section{Results}

\section{Test Results of Mathematical Communication Ability Test Instruments}

In this study the techniques used to determine the validity or legitimacy of the instrument is the product moment correlation technique with rough numbers. If $r_{x y}>$ rtabel at significance level of 5\% means that the item (items) are valid, otherwise if $r_{x y}<r_{\text {tabel }}$ then the item is not valid or have no requirements. After calculation, the obtained interpretation of the validity of each item.

Table 2. Calculation and Interpretation Validity of Items

\begin{tabular}{ccccccccc}
\hline Item & $\boldsymbol{\Sigma X}$ & $\boldsymbol{\Sigma} \mathbf{Y}$ & $\boldsymbol{\Sigma X}^{\mathbf{2}}$ & $\boldsymbol{\Sigma Y}^{\mathbf{2}}$ & $\mathbf{\Sigma X Y}$ & $\mathbf{N}$ & $\mathbf{r}_{\mathbf{x y}}$ & Interpretation \\
\hline 1 & 71 & & 241 & & 959 & & .403 & Feasible \\
2 & 56 & & 158 & & 762 & & .409 & Feasible \\
3 & 72 & 376 & 228 & 5116 & 978 & 30 & .507 & Feasible \\
4 & 59 & & 167 & & 797 & & .401 & Feasible \\
5 & 62 & & 188 & & 854 & & .495 & Feasible \\
6 & 56 & 160 & & 766 & & .429 & Feasible \\
\hline
\end{tabular}

Furthermore, the significant test product moment correlation with the following formula:

$t_{\text {hitung }}=\frac{\mathrm{r} \sqrt{\mathrm{n}-2}}{\sqrt{1-\mathrm{r}^{2}}} \quad($ Sugiyono, 2012)

Information:

$\mathrm{r}$ : coefficient validity of each item

$\mathrm{N}$ : Number of participants test

Validity testing is done by comparing the value of $\mathrm{t}$ count and $\mathrm{t}$ table from the distribution $\mathrm{t}$ with a level of confidence $\alpha=0.05$. For the significance criteria of the rxy value test, if $t$ count $\geq \mathrm{t}$ table, the validity is significant.

From the test results obtained by the validity of each item presented in the following table:

Table 3. Validity Every Items

\begin{tabular}{cccc}
\hline Item & t count & t table & Interpretation \\
\hline 1 & 7.4848905 & 2.0484 & valid \\
2 & 5.141893 & 2.0484 & valid \\
3 & 5.3264251 & 2.0484 & valid \\
4 & 4.867049 & 2.0484 & valid \\
5 & 4.7357189 & 2.0484 & valid \\
6 & 3.2825071 & 2.0484 & valid \\
\hline
\end{tabular}

From Table 3 it can be seen that out of the six questions that have been tested all matter has a valid interpretation, because the value of $t$ count obtained from each question is greater than the value of $t$ table. 
An instrument is said to be reliable if the instrument is believed to be used as a data collector. About the reliability analysis using Cronbach Alpha formula. From the data processing, obtained the results as in the following table.

Table 4. Reliability Every Items

\begin{tabular}{ccccccccccc}
\hline Item & $\sum \mathbf{X}$ & $\sum \mathbf{Y}$ & $\sum \mathbf{X}^{\mathbf{2}}$ & $\sum \mathbf{Y}^{\mathbf{2}}$ & $\mathbf{n}$ & $\mathbf{S i}^{\mathbf{2}}$ & $\sum \mathbf{S i}^{\mathbf{2}}$ & $\mathbf{S t}$ & $\mathbf{r}_{\mathbf{1 1}}$ & Interpretasi \\
\hline 1 & 137 & & 643 & & & -414.19 & & & & \\
2 & 53 & & 211 & & & -42.861 & & & & \\
3 & 141 & & 681 & & & -438.75 & & & \\
4 & 135 & 663 & 617 & 14159 & 6 & -403.42 & -1824.8 & -9850.42 & .9777 & Very High \\
5 & 147 & & 703 & & & -483.08 & & & & \\
6 & 50 & 162 & & -42.444 & & & & \\
\hline
\end{tabular}

From Table 4 it can be seen that all of the eight questions that have been tested very high reliability of interpretations. Reliability qualifications are modified from other researchers namely Hendriana \& Sumarmo (2014). To see any problem distinguishing it should be done distinguishing calculation. From the data processing, obtained the following results:

Table 5. Calculation and Interpretation differentiator Every Distinguishing Power Items

\begin{tabular}{ccccccc}
\hline Item & JBA & JBB & JSA & SMI & D & Interpretation \\
\hline 1 & 44 & 16 & 9 & 6 & .52 & Well \\
2 & 32 & 0 & 9 & 6 & .59 & Well \\
3 & 47 & 22 & 9 & 6 & .46 & Well \\
4 & 45 & 19 & 9 & 6 & .48 & Well \\
5 & 46 & 27 & 9 & 6 & .35 & Enough \\
6 & 27 & 5 & 9 & 6 & .41 & Well \\
\hline
\end{tabular}

From Table 5 it can be seen that the eight questions that have been calculated power pembedanya there are only three questions that have a good interpretation, and the three questions that have sufficient interpretation. To know about the hard, medium, or is it necessary to do the calculation of each item on the difficulty index. From the calculation of the data, showed the following results.

Table 6. Calculation and Interpretation of Trouble Index of Difficulty Items

\begin{tabular}{ccccccc}
\hline Item & JBA & JBB & JSA & SMI & IK & Interpretation \\
\hline 1 & 44 & 16 & 9 & 6 & .56 & Medium \\
2 & 32 & 0 & 9 & 6 & .30 & Difficult \\
3 & 47 & 22 & 9 & 6 & .64 & Medium \\
4 & 45 & 19 & 9 & 6 & .59 & Medium \\
5 & 46 & 27 & 9 & 6 & .68 & Medium \\
6 & 27 & 5 & 9 & 6 & .30 & Difficult \\
\hline
\end{tabular}

From Table 6 it can be seen that out of the six questions that have been calculated index of distress are all questions that included about being. 
24 Fadhillah \& Hermawati, Analysis of Mathematical Communication Ability and Self Regulated Learning Mathematics Student's of Class IX SMP Negeri 2 Cilamaya Kulon

\section{The Results of The Self Regulated Learning Questionnaire Trial}

The instrument used to measure mathematical self-regulated learning is a set of questions or written statements. The attitude scale questionnaire consists of 40 statements, 20 positive statements and 20 negative statements from 9 self regulated learning mathematical indicators of students. Each statement has a weighted value that has been determined based on a Likert scale, namely a statement with 4 alternative answers with the highest score of 4 and the lowest 1.

The choice of response used in this study is $\mathrm{SA}=$ Strongly Agree; $\mathrm{A}=$ Agree $\mathrm{D}=$ Disagree; $\mathrm{SD}=$ Strongly Disagree. In this study the techniques used to determine the validity or legitimacy of the instrument is the product moment correlation technique with rough numbers.

Test criteria with a significant level of $5 \%$ are:

If the value of sig (2-tailed) $<.05$ and Pearson Correlation is positive, then the item about the questionnaire is valid

If the value of sig (2-tailed) $<.05$ and Pearson Correlation is negative, then the item about the questionnaire is invalid

If the sig (2-tailed) value is $>.05$, then the item about the questionnaire is invalid

After calculation, the obtained interpretation of the validity of each item.

Table 7. Calculation and Interpretation Validity of Items

\begin{tabular}{cccc}
\hline Item & Sig. & Pearson Correlation & Interpretation \\
\hline 1 & .007 & .480 & Valid \\
2 & .000 & .803 & Valid \\
3 & .002 & .546 & Valid \\
4 & .005 & .496 & Valid \\
5 & .005 & .496 & Valid \\
6 & .007 & .480 & Valid \\
7 & .000 & .729 & Valid \\
8 & .000 & .624 & Valid \\
9 & .002 & .546 & Valid \\
10 & .000 & .749 & Valid \\
11 & .000 & .769 & Valid \\
12 & .000 & .817 & Valid \\
13 & .000 & .778 & Valid \\
14 & .000 & .758 & Valid \\
15 & .000 & .797 & Valid \\
16 & .005 & .496 & Valid \\
17 & .000 & .744 & Valid \\
18 & .007 & .480 & Valid \\
19 & .000 & .803 & Valid \\
20 & .000 & .744 & Valid \\
21 & .007 & .480 & Valid \\
\hline
\end{tabular}




\begin{tabular}{llll}
\hline 22 & .000 & .749 & Valid \\
23 & .000 & .825 & Valid \\
24 & .000 & .744 & Valid \\
25 & .000 & .803 & Valid \\
26 & .000 & .830 & Valid \\
27 & .000 & .787 & Valid \\
28 & .000 & .707 & Valid \\
29 & .000 & .838 & Valid \\
30 & .000 & .777 & Valid \\
31 & .000 & .834 & Valid \\
32 & .000 & .794 & Valid \\
33 & .000 & .870 & Valid \\
34 & .000 & .795 & Valid \\
35 & .000 & .803 & Valid \\
36 & .000 & .849 & Valid \\
\hline
\end{tabular}

From Table 7 it can be seen that out of forty questionnaires that have been tested are all about interpretations.

An instrument is said to be reliable if the instrument is believed to be used as a data collector. About the reliability analysis using Cronbach Alpha formula. From the data processing, obtained the results as in the following table.

Table 8. Reliability Every Items

Case Processing Summary

\begin{tabular}{cccc}
\hline & & $\mathbf{N}$ & $\boldsymbol{\%}$ \\
\hline \multirow{4}{*}{ Cases } & Valid & 30 & 100.0 \\
& Excludeda & 0 & .0 \\
& Total & 30 & 100.0 \\
\hline
\end{tabular}

a. Listwise deletion based on all variables in the procedure.

Reliability Statistics

Cronbach's $\mathbf{N}$ of Items

\begin{tabular}{c|c}
\multicolumn{2}{c}{ Alpha } \\
\hline .977 & 36 \\
\hline
\end{tabular}

From Table 8 it can be seen that all of the eight questions that have been tested very high reliability of interpretations.

\section{Discussion}

The discussion of the results of this study is an explanation of the findings in the field with the formulation of the results of the instrument trials. Researchers tested the validity, reliability, difficulty index, and differentiation of mathematical communication ability test questions. 
The researcher also tested the validity and reliability of the self regulated learning attitude scale questionnaire. This research was conducted in class IX C for 2 meetings, namely one meeting to test mathematical communication ability and one more meeting to test the selflearning attitude scale questionnaire. The trial results were processed with the help of Microsoft Excel and IBM SPSS 20.0 software, as in Table 3 all the items in question proved valid for mathematical communication ability test questions and as in Table 7, all question items proved valid for self regulated learning scale questionnaire. Then as in table 4 with the help of Microsoft Excel, the results of calculation of reliability are very high for the results of mathematical communication ability tests, and for self-regulated learning attitude questionnaires with reliability results through Cronbach Alpha statistical tests which are assisted by IBM SPSS 20.0 software in table 8 is equal to .977 means that the data used is reliable. From Table 5 it can be seen that the eight questions of mathematical communication ability that have been calculated for distinguishing each question obtained five questions that have good interpretations, and one question that has sufficient interpretation. From Table 6 it can be seen that from the six questions of the mathematical communication ability that have been calculated for the difficulty index, there are four questions including the medium problem category and two difficult questions.

Requirements for instruments to measure mathematical communication skills, mathematical understanding, and self-regulated learning as other instruments must meet certain conditions including, must be valid both the validity of the content and advance validity; reliable, has a good distinguishing power, and the level of difficulty is good too (Tandilling, 2012).

This trial analysis is very important, because it is an important requirement before a test instrument to measure students' abilities is given. This is in line with the opinion Tandilling (2012) through instrument testing to measure mathematical communication skills, mathematical understanding, and self regulated learning in high school students, instruments are available to measure the validity and reliability of instruments that enable researchers to continue taking data for the continuation of writing.

\section{CONCLUSION}

Based on the results of research and data analysis, it can be concluded that the communication ability test instrument and self regulated learning in junior high school students are empirically declared valid and feasible to use.

\section{REFERENCES}

Alamiah, U. S., \& Afriansyah, E. A. (2017). Perbandingan Kemampuan Komunikasi Matematis Siswa antara yang Mendapatkan Model Pembelajaran Problem Based Learning dengan Pendekatan Realistic Mathematics Education dan Open Ended. Jurnal "Mosharafa," 6(2), 207-216.

Asnawati, S. (2016). Peningkatan Kemampuan Komunikasi Matematis Siswa SMP dengan Pembelajaran Kooperatif Tipe Teams-Games-Tournaments. Jurnal Euclid, 3(2), 561567.

Azka, R., \& Santoso, R. H. (2015). Pengembangan Perangkat Pembelajaran Kalkulus untuk Mencapai Ketuntasan dan Kemandirian Belajar Siswa. Jurnal Riset Pendidikan Matematika, 2(1), 78-91.

Bernard, M. (2015). Meningkatkan Kemampuan Komunikasi dan Penalaran serta Disposisi Matematik Siswa SMK dengan Pendekatan Kontekstual Melalui Game Adobe Flash CS 
4.0. Infinity Journal, 4(2), 197-222.

Budiyanto, A. M., \& Rohaeti, E. E. (2014). Mengembangkan Kemampuan Berpikir Kreatif dan Kemandirian Belajar Siswa SMA melalui Pembelajaran Berbasis Masalah. Jurnal Pengajaran MIPA, 19(2), 166-172.

Chotimah, S. (2015). Upaya Meningkatkan Kemampuan Komunikasi Matematik Siswa SMP di Kota Bandung dengan Pendekatan Realistic Mathematics Educations pada Siswa SMP di Kota Bandung. Jurnal Didaktik, 9(1), 26-32.

Darma, Y., Firdaus, M., \& Haryadi, R. (2016). Hubungan Kemandirian Belajar terhadap Kemampuan Pemecahan Masalah Matematis Mahasiswa Calon Guru Matematika. Jurnal Edukasi, 14(1), 169-178.

Elida, N. (2012). Meningkatkan Kemampuan Komunikasi Matematik Siswa Sekolah Menengah Pertama melalui Pembelajaran Think-Talk-Write (TTW). Infinity Journal, $1(2), 178-185$.

Fadhillah, F. M., \& Sumarna, A. (2017). Meningkatkan Kemampuan Komunikasi Matematik Siswa SMP dengan Menggunakan Pendekatan Problem Solving. Prosiding Seminar Matematika Dan Pendidikan Matematika, 5, 92-100.

Gardenia, N. (2016). Peningkatan Kemampuan Pemahaman dan Komunikasi Matematis Siswa SMK melalui Pembelajaran Konstruktivisme Model Needham. Formatif: Jurnal Ilmiah Pendidikan MIPA, 6(2), 110-118.

Haerudin. (2013). Pengaruh Pendekatan SAVI terhadap Kemampuan Komunikasi dan Penalaran Matematik serta Kemandirian Belajar Siswa SMP. Infinity Journal, 2(2), 183193.

Haji, S., \& Abdullah, M. I. (2016). Peningkatan Kemampuan Komunikasi Matematika melalui Pembelajaran Matematika Realistik. Infinity Journal, 5(1), 42-49.

Hendriana, H., \& Kadarisma, G. (2019). Self-Efficacy dan Kemampuan Komunikasi Matematis Siswa SMP. JNPM (Jurnal Nasional Pendidikan Matematika), 3(1), 153. https://doi.org/10.33603/jnpm.v3i1.2033

Hendriana, H., \& Sumarmo, U. (2014). Penilaian Pembelajaran Matematika. Bandung: Reflika Aditama.

Kurnia, R. D. M., Mulyani, I., Rohaeti, E. E., \& Fitrianna, A. Y. (2018). Hubungan antara Kemandirian Belajar dan Self Efficacy terhadap Kemampuan Komunikasi Matematis Siswa SMK. Jurnal Ilmiah Pendidikan Matematika, 3(1), 59-64. https://doi.org/10.26877/jipmat.v3i1.2183

Nuriadin, I. (2015). Pembelajaran Kontekstual Berbantuan Program Geometer's Sketchpad dalam Meningkatkan Kemampuan Koneksi dan Komunikasi Matematis Siswa SMP. Infinity Journal, 4(2), 168-181.

Purnamasari, S., \& Herman, T. (2016). Penggunaan Multimedia Interaktif terhadap Peningkatan Kemampuan Pemahaman dan Komunikasi Matematis, serta Kemandirian Belajar Siswa. EduHumaniora: Jurnal Pendidikan Dasar, 8(2), 178-185.

Rahmi, S., Nadia, R., Hasibah, B., \& Hidayat, W. (2017). The Relation Between SelfEfficacy Toward Math with The Math Communication Competence. Infinity Journal, 6(2), 177-182. https://doi.org/10.22460/infinity.v6i2.p177-182

Rosita, C. D. (2008). Kemampuan Penalaran dan Komunikasi Matematis: Apa, Mengapa, dan Bagaimana Ditingkatkan pada Mahasiswa. Jurnal Euclid, 1(1), 33-46.

Sugiyono. (2012). Metode Penelitian Kuantitatif Kualitatif dan $R \&$ D. Bandung: Alfabeta. 
28 Fadhillah \& Hermawati, Analysis of Mathematical Communication Ability and Self Regulated Learning Mathematics Student's of Class IX SMP Negeri 2 Cilamaya Kulon

Tandilling, E. (2012). Pengembangan Instrumen untuk Mengukur Kemampuan Komuikasi Matematik, Pemahaman Matematik, dan Self Regulated Learning Siswa dalam Pembelajaran Matematik di Sekolah Menengah Atas. Jurnal Penelitian Pendidikan, 13(1), 24-31. https://doi.org/10.1024/1422-4917/a000459

Umar, W. (2012). Membangun Kemampuan Komunikasi Matematis dalam Pembelajaran Matematika. Jurnal Infinity, 1(1), 1-9.

Yuliani, A. (2015). Meningkatkan Kemampuan Komunikasi Matematik pada Mahasiswa melalui Pendekatan Contextual Teaching Learning (CTL). Infinity Journal, 4(1), 1-9. 